\title{
Presentasi Diri Etnik Cina Bangka dalam Hubungan Bisnis dengan Etnik Melayu Bangka
}

\author{
Agustina Zubair \\ Dosen Ilmu Komunikasi Universitas Mercu Buana Jakarta,
}

\begin{abstract}
Abstrak
Artikel ini disusun berdasarkan penelitian mengenai kompetensi komunikasi antarbudaya etnik Cina Bangka dalam hubungan bisnis dengan etnik Melayu Bangka. Fenomena menarik dari keberadaan etnik Cina Bangka dan aktivitas bisnisnya adalah berkaitan dengan reaksi yang ditunjukkan oleh seorang etnik Cina ketika etnik ini berkemauan seperti kelompok budaya yang dominan yaitu etnik Melayu Bangka seperti belajar bahasa, tata cara berbusana, berbicara, condong bergaul dengan kelompok budaya Melayu, sehingga meminimalkan perbedaan latar belakang budaya yang terbawa oleh individu minoritas. Apa yang dicapai etnik Cina Bangka dan Melayu Bangka dapat dipandang sebagai sesuatu yang terbentuk dari proses pembelajaran, dari proses pengalaman yang panjang, yang disampaikan dan dipelajari melalui interaksi dalam keluarga dan lingkungannya.
\end{abstract}

Kata kunci : presentasi diri, etnik, budaya

\begin{abstract}
This article is based on research into intercultural communication competence Bangka ethnic Chinese business relations with ethnic Malay Bangka. Interesting phenomenon of the existence of ethnic Chinese Bangka and business activity is related to the reaction shown by an ethnic Chinese as willing as this ethnic group dominant culture that is ethnic Malay Bangka like learning a language, dress etiquette, talking, hanging out with the group leaning Malay culture, thereby minimizing differences in cultural backgrounds brought by minority individuals. What was achieved ethnic Chinese and Malays Bangka Bangka be seen as something that is formed from the learning process, from the long experience, delivered and learned through interaction in the family and the environment.
\end{abstract}

Keywords : self presentasion, ethnic, culture

\section{Pendahuluan}

Artikel ini disusun berdasarkan penelitian mengenai kompetensi komunikasi antarbudaya etnik Cina Bangka dalam hubungan bisnis dengan etnik Melayu Bangka. Fenomena menarik dari keberadaan etnik Cina Bangka dan aktivitas bisnisnya adalah berkaitan dengan reaksi yang ditunjukkan oleh seorang etnik Cina ketika etnik ini berkemauan seperti kelompok budaya yang dominan yaitu etnik Melayu Bangka seperti belajar bahasa, tata cara berbusana, berbicara, condong bergaul dengan kelompok budaya Melayu, sehingga meminimalkan perbedaan latar belakang budaya yang terbawa oleh individu minoritas. Apa yang dicapai etnik Cina Bangka dan Melayu Bangka dapat dipandang sebagai sesuatu yang terbentuk dari proses pembelajaran, dari proses pengalaman yang panjang, yang disampaikan dan dipelajari melalui interaksi dalam keluarga dan lingkungannya. 
Dalam interaksi, masing-masing individu memiliki kompetensi komunikasi yang diperoleh dari hasil sosialisasi budayanya. Keseluruhan pengalaman interaksi dengan budayanya menjadi pengetahuan, seperangkat ketrampilan dengan berbagai motivasi apabila berinteraksi dengan kelompoknya. Demikianjugapengalaman interaksi dengan individu lain menjadi pengetahuan, seperangkat ketrampilan dan jalinan hubungan dibentuk oleh serangkaian motivasi untuk komunikasi dalam menjalin hubungan. Dialektik dari persepsi dan pengalaman interaksi antarbudaya menempatkan individulah yang memberikan makna pada setiap tindakannya. Keseluruhan pemahaman komunikasi dari hasil interaksi dan proses belajar etnik Cina Bangka selama tinggal dan menetap turun menurun dari satu generasi ke generasi di tanah Bangka akan membentuk pengetahuan bagaimana melakukan komunikasi dengan etnik setempat dalam hal ini etnik Melayu, inilah yang disebut sebagai kompetensi komunikasi (communication competence). Kompetensi komunikasi merupakan indikasi kemampuannya untuk mengetahui dengan siapa ia berkomunikasi, kapan berkomunikasi, di mana berkomunikasi dan seperangkat tindakan yang diperlukan untuk dapat menangkap gambaran, kejelasan, perbandingan serta menginterpretasikan simbol-tanda dan makna yang terkandung di dalamnya. Kompetensi komunikasi akan berkaitan dengan bagaimana ia berperilaku dan bertindak dalam berkomunikasi dan mengetahui bagaimana membangun komunikasi bedasarkan situasi dan kondisi (konteks) yang melingkupinya.

Penelitian-penelitian sebelumnya terutama penelitian tentang etnik Cina di Indonesia, masih seputar pada proses akulturasi, integrasi dan bagaimana etnik Cina berhubungan dengan etnik lain dalam kehidupan sosial dan budaya sehari-hari. Masih sangat sedikit yang mengaitkannya dengan kompetensi komunikasi antarbudaya dalam hal ini mengenai taktik-taktik presentasi diri, apalagi dalam konteks hubungan bisnis. Seperti yang diungkapkan oleh Beamer dan Varner (2008) bahwa komponen penting dari perpaduan budaya adalah keahlian dalam mempraktekkan atau menempatkan pengetahuan kita tentang budaya orang lain.

\section{Fokus Penelitian}

Fokus kajian penelitian ini akan mengungkap pengalaman individu etnik Cina Bangka selama berinteraksi memadukan perbedaan-perbedaan dan menemukan persamaan budaya sehingga membentuk kompetensi komunikasi antarbudaya utamanya taktik-taktik presentasi diri konteks hubungan bisnis. Karena fokus kajian adalah pengalaman individu, maka ada keyakinan yang mengatakan bahwa manusia itu aktif menginterpretasikan pengalaman-pengalamannya atau aktif memberi makna terhadap pengalamannya, sehingga tradisi yang digunakan dalam penelitian ini adalah tradisi fenomenologi. Penelitian ini merujuk pada pemikiran paradigma interpretif (pendekatan subyektif). Dalam konteks penelitian sosial, paradigma interpretif digunakan untuk melakukan interpretasi dan memahami alasan-alasan dari para pelaku terhadap tindakan sosial yang mereka lakukan.

\section{Kerangka Teoritis}

Linda Beamer dan Iris Varner (2008) dalam bukunya Intercultural Communication in the Global Workplace 
secara khusus menyatakan mengenai kebutuhan akan kompetensi komunikasi antarbudaya untuk kepentingan bisnis. Selama ini bisnis selalu dikaitkan dengan bidang-bidang finansial, studistudi pasar, model-model manajemen, pemasaran, asuransi dan akunting tanpa sedikitpun menyinggung tentang budaya dan bagaimana peran budaya dalam bisnis. Menurut Beamer dan Varner, fenomena budaya memang tidak terukur seperti halnya keuangan yang berkaitan langsungdenganbisnis. Merekamenyebut data keuangan sebagai hard data dan budaya sebagai soft data. Bagaimanapun menurut mereka budaya tidak dapat disangkal merupakan faktor penting. Sementara sering terjadi jika suatu bisnis gagal, orang baru melihat budaya sebagai elemen kunci. Lebih lanjut Beamer dan Varner mengatakan komunikasi bisnis adalah komunikasi antarbudaya. Untuk mengkomunikasikan sesuatu kepada oranglainyangberbedabudaya, seseorang membutuhkan pemahaman tentang budaya orang tersebut dan kompetensi komunikasi bisnis antarbudaya tersebut bisa dipelajari. Beammer dan Varner mengakui bahwa beberapa penelitian hanya mengkaji komunikasi antarbudaya saja berdasarkan latar belakang bangsa, daerah/wilayah, pelatihan internasional atau bisnis internasional. hanya sedikit yang khusus mengkaji penerapan langsung komunikasi antarbudaya ke dalam hubungan bisnis.

Untuk memelihara citra diri yang stabil, orang melakukan "pertunjukan" (performance) dihadapan khalayak. Dalam hal ini seorang pebisnis dari etnik Cina bisa jadi memiliki ketegangan diatas karena perannya tersebut memiliki peluang yang besar untuk melakukan apa yang mungkin dilakukannya secara spontan di depan rekan bisnisnya dan tidak sesuai dengan harapan etnik Melayu atau berhasil menjaga citra diri yang stabil sebagai seorang pebisnis. Berkaitan dengan hal tersebut Goffman memusatkan perhatian pada dramaturgi yaitu pandangan atas kehidupan sosial sebagai rangkaian pertunjukan drama yang mirip dengan pertunjukan drama di panggung. Pendekatan dramaturgis Goffman fokus pada pandangan bahwa ketika manusia berinteraksi dengan sesamanya, ia ingin mengelola kesan yang ia harapkan tumbuh pada orang lain terhadapnya. Untuk itu setiap orang melakukan pertunjukan terhadap orang lain. Misi kaum dramaturgis adalah memahami dinamika sosial dan menganjurkan kepada mereka yang berpartisipasi dalam interaksi tersebut untuk membuka topeng para pemainnya untuk memperbaiki kinerja mereka.

\section{Dalam pandangan dramaturgi} tentang kehidupan sosial, makna bukanlah warisan budaya, sosialisasi atau tatanan kelembagaan atau perwujudan dari potensi psikologis dan biologis, yang lebih penting lagi makna bersifat behavioral, secara sosial terus berubah, arbitrer dan merupakan ramuan interaksi manusia. Makna atas suatu simbol, penampilan atau perilaku sepenuhnya bersifat serba mungkin, sementara dan situasional, maka fokus pendekatan dramaturgi adalah bukan apa yang orang lakukan, apa yang ingin mereka lakukan atau mengapa mereka melakukan melainkan bagaimana mereka melakukannya. Dramaturgi menekankan dimensi ekspresi/impresif aktivitas manusia, yakni bahwa makna kegiatan manusia terdapat dalam cara mereka mengekpresikan diri dalam interaksi dengan orang lain yang juga ekspresif. Oleh karena perilaku manusia bersifat ekspresif inilah perilaku manusia bersifat 
dramatik. Goffman mengasumsikan seperti dikutip oleh Mulyana (2004:112) bahwa ketika orang-orang berinteraksi, mereka ingin menyajikan suatu gambaran diri yang akan diterima orang lain. Goffman menyebut menyebut upaya itu sebagai pengelolaan kesan (impression management), yakni teknik yang digunakan aktor untuk memupuk kesankesan tertentu dalam situasi tertentu untuk mencapai tujuan tertentu. Goffman menyebut aktivitas untuk mempengaruhi orang lain itu sebagai pertunjukan (performance). Sebagai pertunjukan itu mungkin kita perhitungkan untuk memperoleh respon tertentu, sebagian lainnya kurang kita perhitungkan dan lebih mudah kita lakukan karena pertunjukan tampak alami, namun pada dasarnya kita tetap ingin meyakinkan orang lain agar menganggap kita sebagai orang yang ingin kita tunjukkan.

\section{Metode Penelitian}

Penelitian ini menjadikan individuindividu dari etnik Cina Bangka dan etnik Melayu Bangka sebagai subyek penelitian. Lebih khusus lagi individu etnik Cina Bangka yang memiliki profesi sebagai pedagang dan menjalankan usahanya di Bangka. Obyek penelitiannya adalah komunikasi verbal dan komunikasi nonverbal etnik Cina Bangka dan etnik Melayu Bangka. Komunikasi verbal dan komunikasi non verbal tersebut dapat diamati pada saat etnik Cina Bangka berkomunikasi dan berinteraksi dengan etnik Melayu Bangka maupun dengan sesama etnik Cina Bangka. Lokasi penelitian dilakukan di Bangka sebagai bagian dari propinsi Bangka Belitung. Dalam studi fenomenologi, lokasi penelitian boleh satu tempat atau tersebar, dengan memperhatikan individu yang akan dijadikan informan baik seseorang atau mereka yang dapat memberikan penjelasan dengan memadai. Penelitian ini menggunakan pendekatan subyektif dengan perspektif interpretif. Thomas R.Lindlof dalam bukunya Qualitative Communication Research Methods (1995:28-33) menyebutnya paradigma interpretif (interpretive paradigm) untuk menunjuk penelitian komunikasi dengan metode kualitatif seperti fenomenologi, etnometodologi, interaksi simbolik, etnografi dan studi budaya. Pada penelitian fenomenologi pengumpulan data dilakukan dengan menggunakan wawancara mendalam. Metode wawancara mendalam ini merupakan esensi dari fenomena yang diamati dan dapatdiceritakandarisudutpandangorang pertama yaitu orang yang mengalaminya langsung.

Pendekatan subyektif erat dengan istilah fenomenologi sebagai istilah generik yang merujuk kepada semua pandangan ilmu sosial yang menempatkan kesadaran manusia dan makna subyektifnya sebagai fokus untuk memahami tindakan sosial. Karena itu tradisi penelitian ini adalah fenomenologi. Littlejohn and Foss (2005:204) mengungkapkan bahwa : The phenomenological tradition concentrates on the conscious experience of the person. Theories in this tradition assume that people activity interpret their experience and come to understand the world by personal experience with it.

Pada penelitian fenomenologi pengumpulan data dilakukan dengan menggunakan wawancara mendalam. Metode wawancara mendalam ini merupakan esensi dari fenomena yang diamati dan dapat diceritakan dari sudut pandang orang pertama yaitu orang yang mengalaminya langsung yaitu etnik Cina Bangka dan etnik Melayu Bangka. 


\section{Temuan Penelitian}

Penelitian ini menemukan bahwa Etnik Cina Bangka berusaha untuk melakukan pengelolaan presentasi diri agar hubungan bisnisnya bisa berlangsung dalam jangka panjang. Pengelolaan presentasi diri merupakan bagian dari Facework yaitu perilaku komunikasi seseorang yang digunakan untuk membangun dan melindungi citra diri juga untuk membangun, melindungi atau mengancam citra diri orang lain. Memelihara citra diri (preventive facework) termasuk didalamnya adalah komunikasi yang dirancang untuk melindungi seseorang dari perasaan terancam oleh kesan orang lain. Citra diri ini membentuk identitas mereka yang berbeda dengan citra diri yang selama ini ada dalam kesan orang Melayu. Pada sub bab di bawah ini akan diuraikan mengenai pengelolaan presentasi diri melalui pemeliharaan citra diri etnik Cina Bangka dengan menggunakan taktik-taktik presentasi diri.

\subsection{Pemeliharaan Citra Diri (preventive facework) Etnik Cina Bangka Melalui Taktik- taktik Presentasi Diri}

Etnik Cina Bangka memahami bahwa orang Melayu Bangka adalah mayoritas dan bisnis mereka mau tidak mau membutuhkan orang Melayu tetapi mereka juga memiliki keyakinan bahwa orang Melayu membutuhkan mereka dalam kebutuhan ekonomi. Keyakinan saling membutuhkan membuat orang Cina Bangka percaya diri dalam menjalin hubungan. Karena merasa juga membutuhkan orang Melayu, orang Cina Bangka berusaha menyesuaikan diri dan selalu menghindari konflik, karena mereka mengatakan mereka lebih baik mengalah untuk kepentingan bisnis jangka panjang. Prinsip mengalah ini terus menerus mereka ungkapkan dalam setiap kesempatan wawancara.

\subsection{Taktik Presentasi diri Etnik Cina Bangka Dalam Konteks Hubungan Bisnis Dengan Etnik Melayu Bangka}

Penelitian mengenai kompetensi komunikasi antarbudaya yang tumbuh pada diri orang Cina Bangka menemukan gambaran bahwa etnik Cina Bangka melakukan pemeliharaan citra diri dengan cara melakukan taktik-taktik presentasi diri. Berdasarkan pengamatan, antara ungkapan verbal dan perilaku non verbal yang dilakukan oleh etnik Cina Bangka selama melakukan pemeliharaan citra diri, kedua-duanya memiliki bobot yang sama dalam arti sama-sama dominan dilakukan oleh etnik Cina Bangka ketika berhadapan dengan etnik Melayu Bangka dalam hubungan bisnis. Model taktik presentasi diri etnik Cina Bangka di bawah ini kemudian disusun dimulai dari ungkapan verbal yang paling dominan dilakukan oleh etnik Cina Bangka yaitu dari kiri ke kanan, demikian juga dengan perilaku non verbal.

Menurut Youn Yun Kim dalam Gudykunst Kim (ed) ( 984:15-16) komunikasi antarbudaya tidak seperti studi komunikasi yang lain dan yang membedakannya dari kajian komunikasi lain adalah tingkat perbedaan yang relatif tinggi pada latar belakang pengalaman pihak-pihak yang berkomunikasi karena adanya perbedaan-perbedaan budaya. Komunikasi antarbudaya sering melibatkan perbedaan-perbedaan ras dan etnik, namun komunikasi antarbudaya juga berlangsung ketika muncul perbedaan-perbedaan yang mencolok tanpa harus disertai perbedaan ras dan etnik. Selanjutnya Gudykunst 
menjelaskan bahwa komunikasi antarbudaya sebagai proses transaksional, proses simbolik yang melibatkan atribusi makna antara individu-individu dari budaya dari dua atau lebih komunitas budaya yang berbeda menegosiasikan makna yang dipertukarkan dalam sebuah interaksi yang interaktif. Jadi titik perhatian dari komunikasi antarbudaya adalah komunikasi antara individu dengan individu dan kelompok dengan kelompok. Asumsi yang mendasari batasan tentang komunikasi antarbudaya tersebut menurut Kim adalah individu- individu yang memiliki budaya yang sama pada umumnya berbagi kesamaankesamaan dalam keseluruhan latar belakang pengalaman mereka daripada orang yang berasal dari budaya yang berbeda. Perbedaan-perbedaan budaya bersama-sama dengan perbedaan lain dalam diri orang memberi kontribusi kepada sifat problematik yang melekat dalam proses komunikasi antar manusia. Sehingga usaha untuk menjalin komunikasi antarbudaya bukanlah persoalan sederhana.

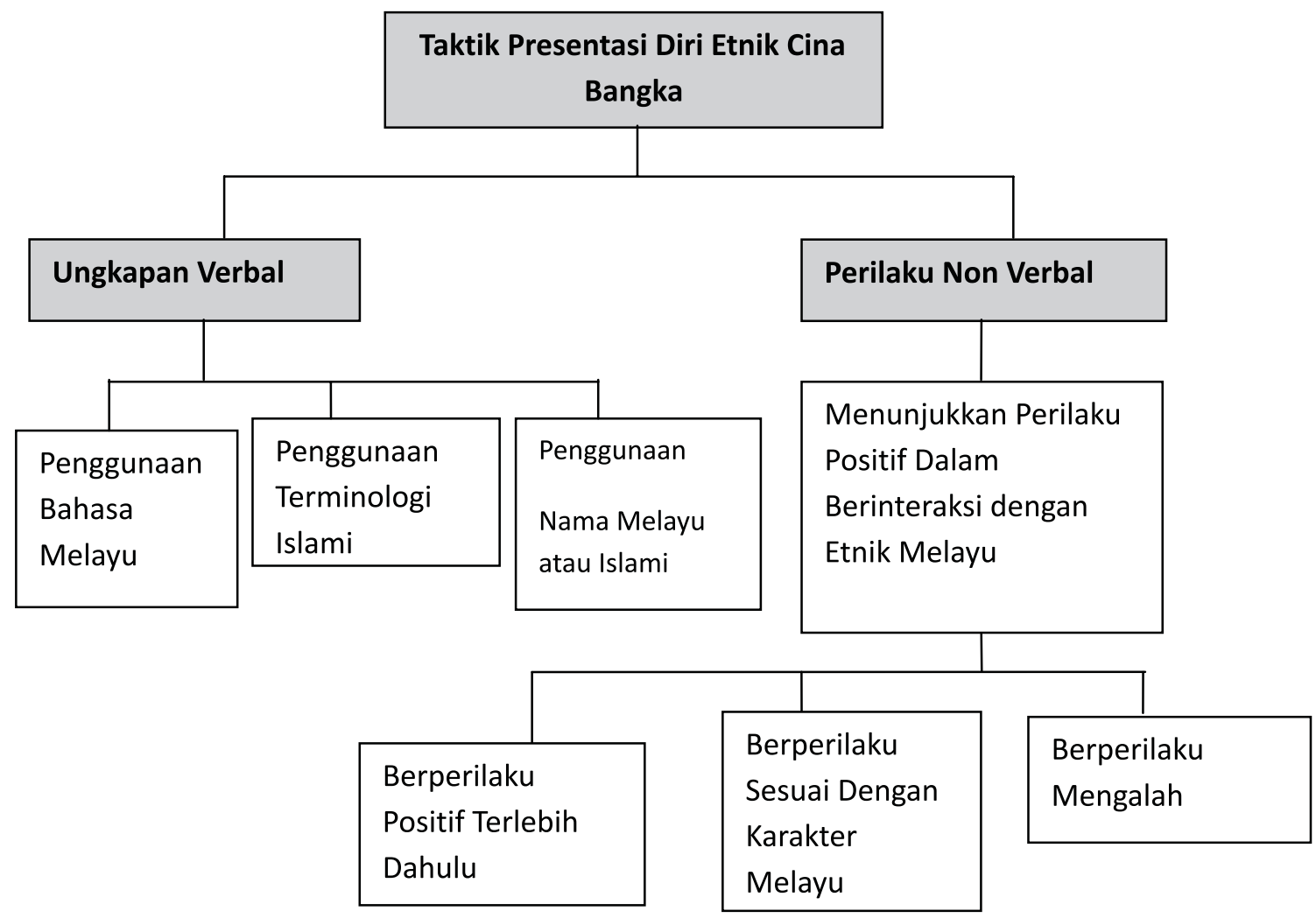

\section{Gambar 1.1. Model Taktik Presentasi Diri Etnik Cina Bangka}

Orang Cina Bangka selalu mengatakan mereka berusaha jujur, bicara apa adanya, tidak mau merugikan orang Melayu, tampaknya memang begitu, tetapi sebetulnya semua itu sudah mereka kelola dan perhitungkan sehingga apa yang mereka lakukan dibalik yang tampak itu tidak terlihat bagi orang luar dalam hal ini orang Melayu. Orang Cina memiliki presentasi diri melalui impression management yang cukup mahir dan professional. Termasuk bagaimana orang-orang Cina ini menggunakan kata-kata yang sering diucapkan oleh orang Melayu yang mayoritas beragama Islam, ucapan-ucapan InsyaAllah atau 
Alhamdulilah akan mereka ucapkan dengan fasih dan paham apa artinya. Ini adalah salah bentuk ketrampilan orang Cina Bangka menarik hati orang Melayu yang memang sudah dipahami oleh orang Cina akan senang jika diambil hatinya. Etnik Cina Bangka seolah-olah sudah menghilangkan identitas dirinya dengan selalu mengucapkan atau menggunakan bahsa Melayu Bangka dalam percakapan sehari-hari terutama ketika berbicara dengan orang Melayu. Tetapi di lain pihak, etnik Cina Bangka masih tetap menggunakan bahasa Cina Hakka di lingkungan internal mereka bahkan juga di tempat umum, tidak sedikit orang Melayu yang juga bisa berbahasa Cina Hakka. Etnik Cina Bangka juga masih kuat mempertahankan tradisi nenek moyang dengan tetap melaksanakan ritualritual sembahyang sesuai ajaran Kong $\mathrm{Fu}$ Chu dan mereka melaksanakannya secara terbuka tanpa dipermasalahkan oleh orang Melayu Bangka selama tidak mengganggu dan tidak berlebihan. Etnik Cina Bangka yang melakukan hubungan bisnis dengan etnik Melayu Bangka, peneliti menggunakan taktik presentasi diri melalui ungkapan verbalnya sebagai berikut.

\subsection{Ungkapan Verbal Etnik Cina Bangka}

\subsubsection{Penggunaan Bahasa Melayu Bangka}

Setiap kali berkomunikasi dengan etnik Melayu Bangka, orang Cina Bangka selalu menggunakan bahasa Melayu, orang Cina Bangka sangat luwes menggunakan bahasa setempat sekaligus dengan dialek dan cengkok Melayu yang mendayu-dayu. Bahkan orang Cina Bangka ini mengikuti kebiasaankebiasaan orang Bangka supaya lebih bisa diterima. Bersikap hati-hati dalam pergaulan untuk menghindari konflik, berusaha untuk ramah supaya tidak boleh dibilang sombong adalah ciri orang Cina. Prinsipnya jangan saling mengganggu, masing-masing punya rezeki. Mereka suka atau tidak suka mau berbaur keluar rumah demi membina hubungan positif dengan tetangga orang Melayu. Karena mereka tahu betul orang Melayu senangnya disapa, tidak suka dicuekin, orang Melayu Bangka paling tidak suka melihat orang dengan perilaku sombong, walaupun sebetulnya mereka juga sekilas tampak sombong. Bagi orang Cina tidak masalah bersikap manis dan ramah dengan orang Melayu asalkan tidak mengganggu satu sama lain dan bisa hidup tentram agar mereka bisa berbinis dengan tenang tanpa gangguan

Orang Melayu yang memiliki karakter terbuka memang punya kebiasaan basa-basi selalu menyapa jika bertemu dengan siapapun yang mereka kenal termasuk dengan orang Cina. Sebaliknya orang Melayu sangat tidak menyukai orang yang sombong dan tidak mau menyapa. Tampaknya orang Cina sangat paham soal ini untuk itu orang Cina yang sudah paham akan selalu menyapa dan berusaha menjawab sapaan dengan ramah jika bertemu dengan orang Melayu. Misalnya bisa disimak dari pernyataan Muk khi dan Sun Yung yang mengungkapkan pendapatnya tentang orang Melayu, karena pengalamannya mereka memahami bagaimana ciri verbal dan non verbal orang Melayu Bangka.

"Orang Melayu jika bertemu akan basa basi menyapa "Nek kemane?"(mau kemana) atau "Ape gawe" (Lagi mengerjakan apa) atau "Ape Cerite" (ada cerita apa) Saat tidak berkenan mereka akan bilang: "Dak pacak"(Tidak bisa) atau "Basing kau lah" (terserah kamu saja). Jika sudah bicara begitu, artinya sudah harga mati, dak kawah ngeladenin 
(Tidak mau meladeni)"(Infroman, 2 Desember 2011)

"Jika orang Melayu setuju akan bilang "Aok (ya) bener juga"atau Aoklah benerlah kate kau tu" (Iya benar kata kata kamu) atau "Bolehlah". Kalau berharap akan bilang : "cemane pacak dak" (Bagaimana bisa tidak)"(Informan, 2 Desember 2011)

Kata-kata 'ape gawe" (ada pekerjaan apa) dan "ape cerite" (ada cerita apa) adalah kata-kata sapaan khas orang Melayu ketika bertemu orang lain. Katakata ini menjadi entry point untuk masuk pada percakapan berikutnya karena memang orang Melayu Bangka dikenal suka mengobrol.Sapaanitu dipahami oleh orang Cina Bangka memiliki konsekuensi untuk mau diam sejenak mengobrol atau bahkan bisa lama tergantung kemana perginya topik pembicaraan. Menurut pengamatan peneliti, orang Cina terlihat kaku dan berusaha untuk luwes terlibat dalam pembicaraan ini, tetapi dengan dukungan penggunaan bahsa Melayu Bangka, kekakuan itu bisa dicairkan. Karena bahasa Melayu Bangka memang terdengar mendayu-dayu.

“Orang Melayu itu terbuka, daya juangnya rendah, dak mau susah. Orang Melayu punya kebiasaan mengucapkan kalimat: "Dak Kawah Susah" atau "Mane ke nek" yang sebetulnya mengekspresikan sikap apatis. "(Informan, 2 Desember 2010)

"Intinya orang Bangka itu terbiasa dengan kata-kata;"Dak kawah nyusah. Kalo terpojok bilang : "Biak lah" atau "Biak ken dielah" atau "mane kenek die lah". Yang artinya secara umum adalah tidak mau mikirin susah dan tidak mau ulet."(Informan, 2 Desember 2010)

Kata-kata "Dak Kawah Susah" yang memiliki arti tidak mau repot-repot atau susah-susah memang kata-kata yang paling sering diucapkan oleh orang
Melayu jika dihadapkan pada sesuatu yang sulit. "Dak Kawah Susah" artinya tidak mau repot-repot. Karena begitu sering diucapkan oleh orang Melayu, orang Cina menjadi paham bahwa karakter orang Melayu adalah tidak mau bekerja keras. Sebetulnya orang Cina menyukai karakter ini karena karakter ini menguntungkan dirinya di sisi yang lain yaitu dia akan mengerjakan pekerjaan atau bisnis-bisnis dimana orang Melayu tidak mau repot menjalankannya. Karakter "Dak Kawah Susah" kemudian dimanfaatkan oleh orang Cina untuk keuntungan dirinya sedemikian rupa dimana orang Melayu Bangka tidak merasakan sebagai suatu gangguan. Satu paket dengan kata-kata "Dak kawah susah" adalah kata-kata "Mane ke nek" artinya terserah mau apa. Implikasi dari tidak mau repot itu adalah tidak mau repot juga dengan konsekuensi dari suatu pekerjaan jadi terserah saja orang lain mau dijadikan seperti apa. Untuk urusan bisnis orang Cina akan dengan senang hati menanggung konsekuensinya asalkan mendatangkan keuntungan bagi bisnisnya. Kata lain yang senada dengan kata-kata "Mane Ke nek lah" yaitu kata-kata "Biak ken die lah" yang artinya biarkan sajalah atau ada kata lain lagi yang bermakna sama yaitu "Basing Kau Lah" yang berarti terserah kamu, mencerminkan sikap tidak perduli atau tidak mau bertanggung jawab atas suatu pekerjaan. Biasanya memang kata-kata ini diucapkan saat orang Melayu saat sedang tidak berkenan. Orang Melayu sangat ekspresif jika mengucapkan sesuatu. Orang Cina sudah memahaminya sebagai sikap yang tidak mau dibantah. Orang Cina sebetulnya tidak memiliki sikap suka berbasa-basi tetapi mereka sudah terbiasa untuk saling sapa, berusaha menegur lebih dahulu jika bertemu 
seperti yang mereka lihat dilakukan oleh orang Melayu dalam pergaulan seharihari baik dalam interaksi bisnis maupun sosial.

\subsubsection{Penggunaan Terminologi Islami Dalam Percakapan}

Etnik Cina Bangka sangat terbiasa mengucapkan lafa-lafal yang sering diucapkan oleh orang Melayu yang mayoritas beragama Islam. Dengan sangat luwes mereka mengucapkan Assalamualaikum jika bertamu atau bertemu dengan orang Melayu, mereka juga dengan tanggap menjawab spontan Waalaikumsalam jika mendengar orang Melayu mengucapkan salam. Ketika diminta untuk hadir di suatu acara atau diundang oleh orang Melayu, mereka juga spontan mengucapkan InsyaAllah.

"Sejak kecil saya ditanamkan bagaimanapun miskinnya, sesuap nasi harus ada. InsyaAllah saya bicara ini, mengatakan ini dari lubuk hati, kita nggak boleh pura-pura."(Informan, 23 Maret 2011)

Orang-orang Cina di Bangka, akan menyapa orang-orang Melayu yang berinteraksi dengannya dan akan menggunakan bahasa Melayu setempat dan juga fasih mengucapkan lafal-lafal seperti Alhamdulilah sekaligus paham artinya.

"Gitu lah ketemu orang ketemu orang kita tanyalah nyapa, apa kabar kew (sebutan Om dalam bahasa Cina kek), Tanyalah sehat Kew, dia pasti jawabnya Alhamdulilah, kitejuga gitu, kaloditanya kabar jawabnya juga Alhambulilah. (Om Lie menyebut Alhamdulilah sangat fasih). Dak susah lah menyapa dan menjawab sapaan orang, tergantung niat, tergantung hati, hanya ingin menunjukkan rasa syukur, bersyukur Alhamdulilah (Ternyata Om Lie pun paham makna kalimat Alhamdulilah). Kami ngomong Alhamdulilah, karena itu tadi, mereka kan nanya, kami sehat nggak?"(Informan, 28 Maret 2011)
Sementara narasumber Min Khie yang berprofesi sebagai pedagang sekaligus anggota DPRD TK I Propisnsi Bangka Belitung tanpa ragu-ragu akan mengucapkan salam Assalamulaiakum secara lengkap apabila bertemu dengan orang Melayu maupun pada saat membuka pidato. Selesai pidato, Min Khie juga akan mengucapkan Wabilahi taufik wal hidayah. Min Khie juga mengatakan akan spontan menjawab waalaikumsalam kalau ada orang Melayu yang mengucapkan salam. Min Khie sepertinya menikmati respon orang Melayu yang antusias jika dia mengucapkan lafal-lafal tersebut. Min Khie mengucapkan kalimat-kalimat dalam bahasa Arab itu dengan sangat fasih.

"Kalau lebaran, kami keliling-kelilinglah ke kawan-kawan. Sebaliknya kalau Imlek kami 3 hari nggak leuar rumah nunggu tamu. Kami masak khususlah untuk tamu-tamu Melayu, walaupun sebenarnya kami juga dak suka makan babi."(Informan, 27 Maret 2011

"Orang Melayu suka kok kalo ade orang Cina bertamu, apalagi kalao mau makan. Melayu suka atau tidak sama kita, tergantung kita sendiri, kita harus bisa-bisa nyesuaikan dengan caracara orang-orang Melayu. Kita selalu ucapkan Assalamualaikum dak masalah artinya juga salam sejahtera kan? Ada temen Melayu kalau ketemu kami juga bilang Assalamualaikum, kami spontan langsung jawab Waalaikumsalam. Kalau saya lagi pidato gitu selesai bicara saya juga ngucapin Wabilahi taufik wal hidayah. Tujuan saya ngucapin itu yaa supaya saya lebih bisa diterima, nyaman untuk diterima. Misalnya ada hajat orang Melayu, kita bertamu ada perkawinan itu. Kalau pas bulan puasa, saya liat juga datang taraweh."(Informan, 27 Maret 2011)

"Kalau diundang orang Melayu, saya suka bilang InsyaAllah, artinya mudahmudahan. Kalau ada kabar orang meninggal saya juga bilang Innalilalhi. Kalau dapet sesuatu saya juga biasa 
bilang Alhamdullilah artinya bersyukur, saya pahamlah. Karena bergaul puluhan tahun, masak kita nggak ngerti."(Informan, 27 Maret 2011)

Orang-orang Cina di Bangka paham benar bahwa orang Melayu selalu suka jika ada orang Cina yang mau berbaur menggunakan bahasa setempat sekaligus mau mengucapkan lafal-lafal yang sering diucapkan oleh Melayu yang mayoritas beragama Islam. Etnik Cina Bangka bagaimanapun mengharapkan orang Melayu menghormatinya, sehingga dia akan berusaha untuk menampilkan dirinya sebagai orang yang memiliki karakter positif. Salah satunya etnik Cina Bangka selalu menyelipkan katakata bijak dalam percakapannya dengan etnik Melayu positif dalam hubungan bisnis maupun dalam pergaulan sosial. Diharapkan melalui ungkapan kata-kata bijak ini, orang Melayu memiliki kesan yang positif tentang orang Cina Bangka.

Etnik Cina Bangka bagaimanapun mengharapkan orang Melayu menghormatinya, sehingga dia akan berusaha untuk menampilkan dirinya sebagai orang yang memiliki karakter positif. Salah satunya etnik Cina Bangka selalu menyelipkan kata-kata bijak dalam percakapannya dengan etnik Melayu positif dalam hubungan bisnis maupun dalam pergaulan sosial. Diharapkan melalui ungkapan kata-kata bijak ini, orang Melayu memiliki kesan yang positif tentang orang Cina Bangka.

\subsubsection{Ungkapan Kata-Kata Bijak Dalam Percakapan}

Ajaran-ajaran Kong Fu Chu dipahami oleh orang-orang Cina yang berusia di atas 50 tahun. Tetapi ajaran ini kemudian disosialisasikan turun menurun ke generasi berikutnya. Sehingga generasi di bawahnya juga memahami mengenai kalimat-kalimat bijak yang sering diucapkan oleh orang tuanya yaitu mengenai ajaran-ajaran tentang hidup dan kehidupan bernuansa harmoni kehidupan manusia. Ini tampaknya sesuai dengan ajaran Islam tentang Ukhuwah Islamiah dan majelis. Persamaan ajaran ini sebetulnya mempermudah asimilasi antara etnik Cina dan Melayu di Bangka. Tetapi ada juga maksud dibalik itu yaitu bahwa orang-orang Cina ini selalu ingin menampilkan diri sebagai orang yang beradab, berhati baik, memiliki sikapsikap yang bijak, suka kerukunan dan kedamaian.

Salah satu tokoh sepuh komunitas Cina di Pangkal Pinang Bangka, selalu mulai berbicara dengan kata-kata bijak. Dia mengedepankan ajaran Kong Fu Chu bahwa kita semua adalah saudara karena sama-sama tinggal di sebuah pulau yang sama. Apalagi orang Cina yang datang ke Bangka sebagai buruh tambang dikatakannya bisa jadi lebih pribumi dari orang Melayu. Ditambah kemudian orang Cina ini menikah dengan orang Melayu, tidak bisa dihindari kita ini sebetulnya ada hubungan saudara. Ucapan-ucapan orang Cina bahwa mereka adalah turunan buruh tambang timah yang didatangkan dari daratan Cina pada masa penjajahan Belanda dapat menjadi penjelasan fakta sejarah yang meyakinkan mereka bahwa sebetulnya nenek moyang mereka lebih pribumi dari orang Melayu itu sendiri. Persepsi ini mempengaruhi bagaimana sikap orang Cina di Bangka ini yang tampak lebih percaya diri dan santai dalam menghadapi orang Melayu, tetapi tetap menjaga hubungan dengan bersikap tidak mengundang konflik.

"Ada kalimat bijak tokoh agama Kong $\mathrm{Fu} \mathrm{Chu}, 4$ penjuru lautan semuanya saudara. Kalimat lainnya keangkuhan, 
kesombongan mengundang rugi. Kerendahan hati membawa berkah." (Informan, 27 Maret 2011)

"Tergantung masing-masing punya ego. Saya bawa amanah, ada amanah, pesan, nasehat yang harus disampaikan"( (Informan, 27 Maret 2011)

Kata-kata tentang kejujuran, persaudaraan, kerendahan hati adalah kata-kata yang sering diucapkan oleh orang-orang Cina. Kata-kata yang menyiratkan bahwa orang-orang Cina yang ada di Bangka ini menginginkan penerimaan dari orang Melayu sebagai satu saudara artinya tidak ada perbedaan, tidak saling menyombongkan atau dengan kata lain janganlah orang Melayu merasa lebih tinggi dari orang Cina, lebih positif kita saling merendahkan hati karena kita satu saudara.

Tokoh Cina lainnya yang juga selalu mengucapkan kata-kata bijak adalah Taufik Salim tokoh sepuh yang dihormati oleh orang-orang Cina di Pangkal Pinang ini dengan suara lembutnya paling sering menyelipkan kata-kata bijak dalam wawancara. Penampilannya memang menyejukkan, tutur katanya halus dan santun. Beliau mengatakan semua manusia ini ada dalam satu kurungan, orang-orang yang ada dalam satu pulau itu adalah saudara. Kita semua saudara karena sama-sama tinggal di sebuah pulau.

"Semua sama, kita dianggap saudara. Orang-orang kita dak beda-bedain. Dak bedain dari mana asalnya. Ajaran Kong $\mathrm{Fu} C \mathrm{Chu}$, dalam kurungan Samudra, dalam satu pulau saudara. Bahasa Cinanya begini : Tsi Hai Zhai Nei - Se hai Che Nei. Bahasa Cina Disekeliling itu Zie Xiong Di ye maksudnya semua dalam kurungan laut adalah saudara, artinya ya satu pulau isinya itu saudara semua. Kita semua adalah saudara karena sama-sama tinggal di sebuah pulau." (Informan, 24 maret 2011)

"Orang Melayu nggak repot, kalau kurang jelas, dijelasin mereka paham, orang Melayu seneng. Orang Cina dagang yang penting kejujuran. Kejujuran bagi orang Cina seperti nyawa ke dua. Iya betul nyawa kami ke dua. Jadi kalo orang dak percaya sama kami, kami seperti kehilangan nyawa "Bahasa Mandarinnya XIEN YONG (Kepercayaan ) SHI (adalah) DI EN (nomor 2) SHENG MING ( Nyawa)." (Informan, 25 maret 2011)

Sedemikian pentingnya kejujuran itu bagi orang Cina menurut Taufik Salim sampai dikatakan sebagai nyawa ke dua. Karena kejujuran memiliki dampak sebuah kepercayaan. Menurut Taufik Salim kalau orang Cina sudah kehilangan kepercayaan maka dia seperti kehilangan nyawa, maksudnya tidak ada lagi orang yang mau berbisnis dengannya itu "sama saja" dengan mematikan bisnis, karena berarti usaha bisnisnya tidak bisa berjalan, penghasilannya berhenti, modalpun menjadi habis. Untuk itulah peneliti melihat orang Cina ini berusaha sedemikian rupa untuk bisa diterima oleh orang Melayu.

\subsubsection{Menggunakan Nama Indonesia atau Nama Yang Bernuansa Islami}

Etnik Cina Bangka selain memiliki nama Cina dan memiliki nama Indonesia. Untuk panggilan sehari-hari di keluarganya mereka menggunakan nama panggilan dalam bahasa Cina, tetapi dalam pergaulan formal seperti di sekolah atau untuk kepentingan bisnis mereka menggunakan nama yang lazim diberikan oleh orang-orang Melayu Bangka. Nama ini menurut mereka penting terutama jika harus berhadapan dengan birokrasi pemerintahan dalam 
urusan perizinan usahanya bahwa huruf dalam bahasa Cina sangat bermakna karena setiap satu huruf mengandung arti.

"Setiap satu huruf Cina itu punya 1 arti" ( Informan)

"Kepekaan orang Cina itu kultur, ade dideretan huruf-huruf Cina. Hurufhuruf ini melatih kepekaan. Misalnya kerja kongsi lebih banyak cekcok. Khong Tsi (Huruf Cina). Kerjasama dua perusahaan lebih banyak tidak berkembang. Huruf Khong Tsi itu dibuat tidak punya kepala, artinya ya itu tidak bisa berkembang."(Informan, 28 Janauri 2011)

Artinya setiap huruf yang ada pada nama Cina mereka juga sarat arti. Untuk itu sebenarnya mereka masih bangga menggunakan nama Cina sebagai penerus tradisi dan bahasa leluhur mereka. Menurut pengamatan peneliti dalam percakapan sehari-hari mereka lebih senang dipanggil dengan nama Melayunya bukan nama Cinanya. Seingat peneliti selama peneliti sekolah dari Taman Kanak-kanak hingga sekolah menengah atas teman-teman peneliti dari kalangan Cina ini masih menggunakan nama-nama Cina asli tanpa menggantikannnya dengan nama yang terkesan Indonesia tetapi saat peneliti melakukan penelitian, semua sudah menggunakan dua nama, nama Cina dan nama Indonesia dengan penggunaannya tergantung kebutuhannya. Tampaknya mereka lebih nyaman jika orang lain hanya mengetahui nama Indonesianya saja, karena seluruh informan memperkenalkan dirinya dengan nama Indonesia dan ketika dengan hati-hati peneliti menanyakan nama Cina mereka, dengan berat hati mereka menjawab dan mengejanya untuk peneliti. Etnik Cina Bangka bagaimanapun ingin terlihat berbaur dengan penduduk setempat, termasuk dengan menyesuaikan nama diri mereka, agar perbedaan dengan etnik Melayu Bangka tidak terlalu lebar, sekaligus untuk kepentingan mereka ketika harus berurusan dengan pemerintahan.

Bersikap mengalah, bersikap positif terlebih dahulu dan sikap-sikap lain yang dianggap oleh orang Cina sebagai sikap yang disukai oleh orang Melayu akan mereka lalukan demi tercapainya lingkungan harmoni yang memadai bagi keberlangsungan bisnis mereka. Perilaku-perilaku yang mencerminkan sikap-sikap di atas akan diungkapkan pada penjelasan di bawah ini.

\subsection{Perilaku Non Verbal Etnik Cina Bangka}

Seperti sudah dipaparkan di atas bahwa pengetahuan etnik Cina Bangka tentang etnik Melayu Bangka tidak hanya membuat mereka memiliki ketrampilan bagaimana harus mengunakan bahasa Melayu Bangka secara tepat, bagaimana harus menggunakan kata-kata dalam bertegur sapa seperti kata-kata tentang kesehatan, kata bijak mengenai kejujuran dan ucapan-ucapan yang mengandung terminologi Islam, tetapi etnik Cina Bangka ini juga memiliki pengetahuan bagaimana harus berperilaku yang sesuai dengan budaya Melayu. Pengetahuan mengenai karakter Melayu Bangka yang diperoleh melalui perjalanan panjang interaksi dengan etnik Melayu membuat etnik Cina Bangka memiliki cara bagaimana menghadapi etnik Melayu agar diterima, terutama agar etnik Melayu ini mendukung bisnisnya dan dapat menciptakan suasana yang aman, nyaman dankondusif bagi perkembangan dan keberlanjutan bisnisnya dalam jangka panjang. 
Etnik Cina di Bangka mau tidak mau harus berhubungan dengan orang Melayu, karena sasarannya tentu saja adalah orang Melayu yang merupakan warga mayoritas. Pandangan ini memperjelas analisa peneliti sebelumnya bahwa orang Cina mau tidak mau harus bersikap ramah untuk menghadapi orang Melayu yang tidak suka orang sombong, orang Cina harus sabar menghadapi orang Melayu yang suka disanjung dan dipuji, orang Cina harus bisa mengatur strategi bisnisnya dengan cantik untuk menghadapi orang Melayu yang tidak mau kerja keras, tidak banyak memperhitungkan untung rugi dan cepat puas hanya dengan untung sedikit. Orang Cina harus mengalah menghadapi orang Melayu yang tampaknya terbuka dan merasa mayoritas. Orang Cina harus mau dan rela menirukan sikap bahkan kata-kata yang sering diucapkan oleh Melayu yang identik dengan Islam walaupun kata-kata tersebut sebetulnya adalah lafal-lafal Islam. Orang Cina harus mengikuti tradisi orang Melayu seperti menghadiri sunatan, bersikap toleran saat bulan puasa dan sikap-sikap lain yang sebetulnya mencerminkan ajaran Islam. Kenapa orang Cina mau tidak mau melakukan itu semua, karena memang sasarannya tidak lain dan tidak bukan dan tidak bisa dihindari adalah orang Melayu sebagai mayoritas.

Pertemanan atau relasi yang positif dengan orang Melayu adalah kondisi yang kondusif untuk bisnis mereka. Untuk itu tidak masalah jika mereka harus selalu menjaga perilaku positif ketika berhadapan dengan etnik Melayu Bangka.

\subsubsection{Menjaga Perilaku Yang Positif Di depan Etnik Melayu Bangka}

Berdasarkan pengalaman orang Cina selama berinteraksi bisnis dengan orang Melayu, orang Cina Bangka mendapatkan pengetahuan bahwa orang Melayu memiliki karakter tidak suka terlalu repot dan kerja keras, cenderung konsumtif, segera menghabiskan uang yang diperoleh, orang Melayu cepat puas, suka dipuji dan disanjung, selain ramah dan terbuka orang Melayu juga bisa muntab (marah besar). Pengetahuan orang Cina tentang sikap-sikap orang Melayu tersebut berdasarkan pengalaman juga, orang Cina Bangka kemudian juga mendapatkan pengetahuan bagaimana cara menghadapinya, ternyata sikapsikap asli ajaran Kong fu Chu yang merupakan ajaran dasar orang Cina bisa dimanfaatkan yaitu mereka harus menghadapinya dengan cara bersikap jujur, bisa dipercaya, mau kerja keras, ramah dan sabar serta prinsip kalau kita positif maka orang lain pasti akan ikut positif. Yang sebetulnya tujuan utamanya bersikap begitu sedemikian rupa adalah agar bisnis mereka bisa terus berlangsung dan berkembang.

"Saya harus bisa memainkan ekspresi. Kalau tidak suka tapi tetap senyum. Sebaliknya walaupun suka tapi tetap diam."(Informan, 2 Desember 2011)

Narasumber Men Khiong secara terus terang mengakui mengenai pentingnya reputasi walaupun dia hanya berpendidikan SMA yang tidak tamat, tetapi memiliki strategi bisnis yang positif. Dalam berbisnis bagi Men Khiong reputasi itu penting untuk membuat orang lain percaya pada kita. Dia akan selalu menampakkan diri sebagai orang positif-positif dan bisa dipercaya.

Seperti yang sudah disinggung di atas, bagaimana orang Cina Bangka yang melakukan hubungan bisnis dengan orang Cina akan memanfaatkan karakter orang Melayu yang suka dipuji, gengsian, konsumtif dan terbuka. Orang Cina akan 
bersikap suka memuji, menaikkan harga diri orang Melayu tersebut, merayu dengan hal-hal yang menjadi kesukaan orang Melayu tersebut. Orang Cina akan berusaha bersikap seramah mungkin, karena dia tahu orang Melayu menyukai orang yang ramah dan tidak sombong. Mereka akan bersikap bahwa antara orang Cina dan Melayu adalah "sama saja", mereka memainkan ini dengan ber dramaturgi seperti yang dilakukan oleh informan Informan 1 yang jelas-jelas mengakuinya sebagai berikut:

"Untuk membina hubungan ini saya berusaha di depan klien menjaga reputasi saya sepositif mungkin, misalnya tidak menunjukkan kalau saya suka berjudi saya tunjukkan saya tidak suka berjudi (Dramaturgi), atau tidak suka minumminum, tapi pada saat tertentu dia mengundang orang-orang, temen 2 nya yang usianya lebih tua dari dia untuk main judi di rumahnya sebagai pengisi waktu. (Saat malam hari tgl 3 desember 2010, saya melihat dia main judi di belakang rumahnya bersama 4 orang temannya, salah satunya saya kenal sebagai kakak kandung dari temen saya saat SMP dan SMA), esoknya saya tanyakan mengapa waktu lampu mati, Men Khiong diem aja dak minta ambilin lampu kecil. Dia menanggapi terus terang, bahwa dia berharap saat itu lampu tidak menyala lagi karena saya sudah menang judi 30 juta, eh nggak taunya listrik nyala lagi, aku jadi Cuma memang 18 juta.)" (Informan, 2 Desember 2011)

Pengakuan Men Khiong menarik sama dengan pengakuan lugas dari nara sumber muda lain yang bernama Yung yung.

"Dalam kehidupan seseorang harus pandai bersandiwara dan menempatkan diri, pada posisi saya terjepit maka yg harus saya lakukan bisa menempatkan diri, bersandiwara." (Informan, 26 Maret 2011)

"Misalnya, sebagai seorang pejabat memaksakan kita aturan-aturan yang tidak masuk akal atau logika saya, maka di depannya tetap mengiyakan, tapi dalam praktek kenyataan kita sesuaikan saja dengan keinginan saya."(Informan, 26 Maret 2011)

Keyakinan ini didasari oleh prinsip bisnis yang harus berlangsung dalam waktu yang panjang dan berkesinambungan, tidak boleh hancur sesaat karena perilaku tidak jujur sehingga orang tidak percaya dengan mereka. Sehingga untuk mendapatkan kepercayaan itu orang Cina akan melakukan apapun termasuk melakukan dramaturgi dimana menutut pengalaman mereka sikap-sikap mereka itu akan disukai oleh orang Melayu.

Orang Cina Bangka sangat percaya dengan prinsip kalau kita positif maka orang lain akan positif, walaupun mereka harus melakukannya berulang-ulang dengan keyakinan dan kesabaran mereka bisa memetik hasilnya yang memang biasanya orang Melayu akhirnya akan menerima mereka dengan positif.

\subsubsection{Berperilaku Positif Terlebih Dahulu}

Bagaimana supaya etnik Cina Bangka diterima oleh orang Melayu selain agar menciptakan rasa aman atau situasi yang kondusif untuk usaha dagangnya. Menurut mereka situasi atau suasana yang harmoni adalah sangat penting dan dibutuhkan untuk perkembangan bisnis mereka. Demi tercapainya suasana yang harmoni orang Cina rela untuk mengalah dan tak lelah berusaha untuk bersikap positif dengan orang Melayu dan mereka punya keyakinan jika mereka positif maka orang lain akan positif walaupun untuk mendapatkan respon positif itu mereka harus melakukannya berkalikali artinya tidak sekali saja sikap positif 
maka orang lain akan positif.

Kata-kata kalau kita positif maka orang lain akan positif yang berulangkali diucapkan beberapa nara sumber juga dikuatkan dengan kata-kata tergantung kita, menurut Min Khi anggota DPRD Bangka, jika mau saling mengerti dan mau menyesuaikan diri dengan cara-cara orang Melayu pasti kita kan diterima, hal itu harus disadari oleh orang Cina karena setiap hari mau tidak mau kita pasti bergaul dengan orang Melayu setiap hari.

"Melayu suka atau tidak sama kita, tergantung kita sendiri, kita harus bisa-bisa nyesuaikan dengan cara-cara orang-orang Melayu." (Informan, 27 Maret 2011)

"Suka nggak suka orang sama kita tergantung kita, kalau kita positif, mereka positiflah. Berteman itu saling mengerti, semua orang kan senang kalau kita mengerti. Kita ni kan bergaul dengan Melayu setiap hari." (Informan, 27 Maret 2011)

'Tergantung kite lah, tergantung hati kite (mungkin maksudnya lebih tepat tergantung ite positif, orang positif lah same kite. Dari dulu-dulu, dari atok-atok (sebutan kakek dalam bahasa Melayu, Iwan dan dedi cukup fasih menyebut atok padahal itu panggilan untuk kakek dalam bahasa Melayu, orang Cina sebetulnya menyebut Kakek dengan Akung) Cina melayu seperti sodare. Semua kota di Bangka menurut ku samelah antara Cina dan Melayu tu saling saudara."(Informan, 24 maret 2011)

"Suka nggak suka orang sama kita tergantung kita, kalau kita baik, mereka baiklah. Berteman itu saling mengerti, semua orang kan senang kalau kita mengerti. Kita ni kan bergaul dengan Melayu setiap hari."(Informan, 27 Maret 2011)

Narasumber-narasumber yang lain juga mengatakan hal yang sama dan selalu dengan kalimat yang sama yaitu kalau kita positif maka orang lain akan positif artinya apakah sebuah interaksi itu akan berlangsung harmoni satau tidak tergantung pada diri kita sendiri. Harus ada niat untuk mau bersikap saling mengerti satu sama lain. Jika kita melakukan itu semua maka selama berlangsung interaksi dengan orang Melayu tidak akan muncul kecemasankecemasan dan hambatan karena kita merasa sudah diterima oleh orang Melayu. Sikap ini sudah dibuktikan oleh orang Cina berhasil dalam menghadapi orang Melayu.

Keyakinan ini juga dimiliki oleh informan lain, bentuk kesabaran untuk terus berusaha bahwa probability peluang untuk mendapatkan apa yang diinginkan itu pasti ada. Asal kita menciptakan banyak peluang dan memanfaatkan banyak peluang. Bahwa hasil akan atau pasti diperoleh. Teruslah berbuat positif, maka pasti orang lain akan berbuat yang sama. Sikap kalau kita baik maka orang lain akan baik menjadi pilihan sikap yang dilakukan oleh orang Cina Bangka ketika berinteraksi bisnis dengan etnik Melayu Bangka. Sikap ini kemudian sudah dibuktikan oleh orang Cina berhasil dalam menghadapi orang Melayu. Prinsip yang diungkapkan oleh informan-informan ini adalah satu keyakinan kalau kita positif maka orang lain akan positif. Kalu kita baik sekali orang lain belum baik, maka kita harus terus menerus positif, maka lama kelamaan orang itu akan positif. Bersikap seperti ini butuh kesabaran dan permaian presentasi diri yang bagus agar emosi tidak tampak keluar. Prinsip informan 6, lebih baik orang lain yang percaya sama kita, jangan kita memaksa orang lain percaya sama kita. Kesabaran mencari informasi tentang orang lain, agar saat berhadapan dengannya kita sudah tahu harus bagaimana. Kesabaran ini juga membimbing orang Cina Bangka 
untuk memilih sikap mengalah atau diam jika terjadi perbedaan dengan orang Melayu Bangka. Untuk bisa bertahan tetap berbuat positif pada orang yang tidak ramah dengan kita membutuhkan kesabaran dan keyakinan bahwa ini akan berhasil. Di bawah ini gambaran bagaimana etnik Cina Bangka memilih mengalah dan diam dalam menghadapi ketidaksesuaian selama berinteraksi dengan etnik Melayu Bangka dengan satu tujuan hubungan baik dan kepentingannya tercapai.

Selain berulang kali informan mengatakan bahwa kejujuran dan kepercayaan itu nyawa ke dua, bahkan sudah menjadi falsafah hidup. Informan juga mengatakan kalau orang-orang Cina harus pandai membawa diri, tidak pamer, tidak berbuat sesuatu yang memancing keonaran, untuk itu orang Cina memilih lebih positif mengalah dan diam jika terjadi sesuatu yang bisa memancing amarah. Mereka harus mau menyesuaikan diri bahkan harus mengucapkan kata-kata yang seharusnya bukan tradisinya sekalipun untuk menjaga supaya mereka tetap survive. Etnik Cina Bangka fokus pada tujuan jangka panjang yaitu hubungan tetap positif dengan orang Melayu yang mau tidak mau akan terus berinteraksi dengannya baik itu dalam hubungan bisnis maupun dalam pergaulan sosial. Demi hubungan positif dan kepentingan bisnisnya bisa dicapai mendorong etnik Cina Bangka untuk berperilaku secara suka rela sesuai dengan karakter Melayu Bangka.

\subsubsection{Berperilaku Sesuai dengan Karakter Melayu Bangka}

Karakter etnik Melayu Bangka menurut etnik Cina Bangka berdasarkan pengalamannya berinteraksi baik dalam hubungan yang bersifat sosial maupun hubungan yang bersifat bisnis adalah orang Melayu Bangka cenderung suka dipuji, untung sedikit sudah senang dan suka pamer, juga tidak bisa melihat orang lain punya sesuatu barang ingin memiliki juga. Etnik Melayu Bangka juga suka sekali ngobrol dan tidak mau repot-repot jika berbisnis, tidak cerewet jika bertransaksi dengan etnik Cina Bangka. Karakter ini dipahami oleh etnik Cina Bangka dan dimanfaatkan untuk mencapai tujuan bisnisnya. Orang Cina Bangka akan berusaha bersikap atau berperilaku sesuai dengan karakter tersebut.

Sikap orang Melayu yang gengsi dan suka pamer, selalu menunjukkan bahwa dia mampu tentunya bisa dimanfaatkan orang Cina dan menguntungkan untuk usaha bisnis mereka. Hi Bie Sie sudah paham bagaimana karakter orang Melayu, sekaligus juga paham bagaimana menghadapinya.

"Karena sudah saling kenal, bisa tahu bisa selektif maka keputusan bisa diambil. Bisa punya harapan positip." (Informan, 2 Desember 2011))

"Karena ku (aku) lah biase bergaul same orang Melayu dari kecik (kecil) enjoy lah, seneng (senang) dengan orang Melayu, karena sudah tau (tahu) cara atau watak-wataknya. Mereka keras juga biselah (bisalah) kalo dak (kalau tidak) tau (tahu) kemauannya die dak nek terima (dia tidak mau terima) ape kate kite (apa kata kita). Kalo orang tu (orang itu) cem tu (seperti itu) yah aku diem jak lah(diam sajalah). Pelan-pelan lah kite kenal-kenal die lebih jauh lah." (Informan, 24 Januari 2011)

Orang Melayu Bangka sudah pasti diketahui sikapnya yang tidak menyukai orang sombong. Ketiga informan di bawah ini juga memiliki pandangan yang sama bahwa untuk bisa diterima oleh orang Melayu maka kita harus 
membuka diri dan mau berbaur, dengan mau mengenal maka kita tidak ragu-ragu atau takut untuk mengambil keputusan sehingga bisa punya harapan positif. Menurut mereka dengan pergaulan, dia bisa mengenal orang lain, hal itu akan memudahkan pendekatan dan penerimaan dari orang lain. Bisa juga sikap orang Cina ini ada maksud bahwa dibalik sikap itu ada motivasi agar usahanya bisa diterima atau bisa mencapai tujuan usaha dagangnya agar laku dan menjadi pelanggan setia atau loyal.

Terkait dengan sikap orang Melayu Bangka yang tidak menyukai orang sombong, etnik Cina Bangka berusaha untuk tidak menonjolkan diri secara mencolok. Etnik Cina Bangka pada umumnya memang tidak menampilkan kekayaan secara mencolok di depan umum, mereka akan menggunakan segala perhiasannya dan kemampuan modalnya jika berada di luar Bangka atau jika ada acara di lingkungan internal mereka.

"Orang padang sama pemikirannya dengan orang Cina. Kalau orang Melayu suka diangkat. Misal e Wah..bapak ini masih muda. Masih muda tapi rumahnya sudah bagus, barang-barangnya bagus". (Informan, 26 Maret 2011)

"Kalau dalam membina hubungan bisnis atau dagang istilanya eee..ku dapat ini, ku kasi ini,kalau sudah berjalan, jalani saja,kalau ada keuntungan, maka seseorang Melayu dianggap berjasa, maka dikasi, dibantu diingat-ingat jasa-jasanya. Atau karena memang ada untung besar maka dibagi ke Melayu."(Informan, 26 maret 2011)

"Walaupun sudah tidak ada hubungan bisnis misalnya ada keuntungan, ingetinget lah pernah ada jasa-jasanya, maka tetap dikasi hadiah, nggak selalu juga hitung untung ruginya. "(Informan, 26 Maret 2011)
"Mereka orang Melayu suka kalau kita maen datang ke rumahnya, apalagi mau makan-makan di rumahnya, minum teh, kalau dekat sama orang Melayu, mereka dak hitung-hitunganlah. Saya pribadi suka bertandang ke rumah diorang ( Yung yung secara fisik tidak seperti orang Cina)."(Informan, 26 Maret 2011)

Yung yung paham bahwa orang Melayu senang jika orang Cina mau berbaur dengan apa adanya, atau mau berkunjung ke rumah tanpa sungkan. Untuk itu Yung yung selalu rajin berkunjung ke rumah orang Melayu, bahkan berkenan untuk makan bersama di dapur orang Melayu.

Tokoh sepuh dalam komunitas Cina di Pangkal Pinang, sering mengucapkan kalimat-kalimat bijak hasil pengalamanpengalaman hidupnya selama berinteraksi positif itu interaksi hidup sehari-hari mapun interaksi bisnis. Dia menjadi paham yang harus dilakukan agar hidup dan usaha bisnisnya bisa berjalan tenang dan nyaman. Menurut Hidup berdampingan dengan tenang antara Melayu dan Cina maka bagi orang yang sudah mampu terutama bagi orang Cina yang kaya, tidak perlu menampakkan kekayaannya secara mencolok sehingga bisa mengundang rasa iri orang lain apalagi orang Melayu. Orang-orang Cina di Bangka memang terlihat hidup dan tampil sederhana jika di luar rumah walaupun sebetulnya dia mampu dan menyekolahkan anakanaknya di Jakarta atau bahkan di luar negeri.

Semua informan Cina memahami karakter orang Melayu yang suka ngobrol. Berkumpul dimana saja sambil ngopi dan ngobrol kesana kemari adalah ciri orang Melayu. Orang Cina akan melayani kesukaan ini dengan ikut berbaur, mengobrol dan minum kopi 
bersama-sama. Dalam pendekatan awal orang Cina akan membuka diri walapun tidak suka dengan cara menawarkan rokok, mengajak minum kopi dan menemani ngobrol mitra bisnisnya yang orang Melayu. Menunjukkan karakter Cina sudah berbaur seperti karakter orang Melayu. Informan orang Cina, mengatakan karakter yang ditiru oleh orang Cina adalah karakter negatif orang Melayu. Orang Cina merasa dipengaruhi oleh hal yang tidak positif, secara tidak langsung informan Cina ini ingin menunjukkan bahwa orang Cina sebelumnya adalah orang dengan karakter yang positif. Orang Cina Bangka selalu mengatakan bahwa kalau orangorang Cina harus pandai membawa diri, tidak pamer, tidak berbuat sesuatu yang memancing keonaran, untuk itu orang Cina memilih lebih positif mengalah dan diam jika terjadi sesuatu yang bisa memancing amarah. Secara rinci akan diuraikan di bawah ini.

\subsubsection{Berperilaku Mengalah}

Prinsip mengalah terlihat dari beberapa informan dalam interaksi dengan orang Melayu terutama yang berkaitan dengan interaksi bisnis, prinsip mengalah dan bahwa kalau kita positif maka orang lain akan positif, mereka yakini betul. Bahwa semua perilaku bisnis kita akan berdampak terhadap kelangsungan dan kesuksesan bisnis. Keyakinan ini juga dimiliki oleh informan lain, bentuk kesabaran untuk terus berusaha bahwa probabiliti peluang untuk mendapatkan apa yang diinginkan itu pasti ada. Asal kita menciptakan banyak peluang dan memanfaatkan banyak peluang. Bahwa hasil akan atau pasti diperoleh. Teruslah berbuat positif, maka pasti orang lain akan berbuat yang sama.
"Orang Melayu kalau marah-marah langsung jak lah, kite ya diem lah dengerin, ngomong pelan-pelan nanti juga nyadarin terus minta maaf. Yang namanya orang minta maaf ya kita maafkanlah. (Informan, 25 Januari 2011)

"Kite tu harus jage temen, jaga pertemananlah, yang penting dalam pertemanan, dalam dagang, dalam bisnis kite harus jujur, dak boleh bohong supaya orang percaya terus same kite."(Informan, 25 Januari 2011)

Semua informan mengatakan modal utama dalam berbisnis adalah kejujuran agar bisa mendapatkan kepercayaan, dengan kejujuran dan kepercayaan mereka yakin bisnis akan lancar. Mereka akan siap mengalah dan sabar untuk mendapatkan kepercayaan dan dianggap jujur oleh orang lain. Demi hubungan positif dan kepentingan bisnisnya bisa dicapai mendorong etnik Cina Bangka untuk berperilaku secara suka rela sesuai dengan karakter Melayu Bangka.

Dalam presentasi diri terdapat ketertiban interaksi yang muncul untuk memenuhi kebutuhan akan pemeliharaan keutuhan diri. Manusia adalah manipulator simbol, mendemontrasikan apa yang dikomunikasikan manusia kepada manusia lainnya ketika mereka berinteraksi dalam situasi sehari-hari. Menurut pengamatan peneliti etnik Cina Bangka termasuk ahli menggunakan simbol dalam berkomunikasi dengan etnik Melayu Bangka ketika mereka berinteraksi secara sosial maupun binis. Ketrampilan atau keahlian komunikasi itu muncul karena etnik Cina Bangka memiliki pengetahuan yang cukup tentang unsur budaya dominan seperti bahasa dan kebiasaankebiasaan orang Melayu Bangka. Seperti yang diungkapkan oleh Goffman (1959:10) bahwa informasi mengenai 
seorang individu membantu untuk mendefinisikan situasi, memungkinkan orang-orang itu untuk mengetahui terlebih dahulu apa yang ia harapkan darinya. Berdasarkan pengetahuan ini, orang tersebut akan mengetahui bagaimana cara terbaik bertindak untuk menghasilkan respon yang diinginkan darinya. Dalam hal ini Etnik Cina Bangka berdasarkan pengalamannya berinteraksi dengan etnik Melayu, dia mendapatkan informasi apa yang diharapkan orang Melayu terhadap dirinya, dari situ dia mengetahui bagaimana cara terbaik untuk berkata-kata (ungkapan verbal) dan bertindak (ungkapan non verbal) supaya mendapatkan respon yang positif dari etnik Melayu.

Etnik Cina Bangka, menurut pengamatan peneliti selalu berusaha untuk tidak mengundang masalah dan sedapat mungkin menjadi bagian dari orang-orang Melayu yang ada di Bangka. Mereka tahu betul bahwa orang Melayu sebetulnya tidak menyukai jika ada orang Cina yang menggunakan bahasa Cina dengan keras dan bebas di sekitar orang Melayu. Orang Melayu akan memandang tidak senang atau meledek jika ada orang Cina yang mengucapkan bahasa Cina dengan keras sehingga terdengar oleh orang-orang di sekitarnya. Orang Cina di Bangka memang mayoritas adalah orang Cina dari suku Hakka, orang Cina suku Hakka kalau berbicara sangat keras dan cepat. Walaupun jarak antara orang yang berbicara itu tidak terlalu jauh. Sehingga supaya mereka bisa diterima oleh orang Melayu, orang Cina pun akan menggunakan bahasa Melayu dalam percakapan sehari-hari. Untuk itu ungkapan verbal yang paling dominan sering terdengar dari etnik Cina Bangka adalah mereka selalu bercakapcakap dengan menggunakan bahasa Melayu Bangka. Menurut pengamatan peneliti, etnik Cina yang ada di Bangka sangat fasih mengucapkan kata-kata dalam bahasa Melayu lengkap dengan intonasi dan irama naik turunnya. Tetapi jika berbicara di kalangan internal orang Cina mereka akan menggunakan bahasa Cina dan cepat berubah menggunakan bahasa Melayu jika berbicara dengan orang Melayu, tetapi jika mereka sesama orang Cina berbicara di depan orang Melayu atau disekitarnya ada orang Melayu, mereka memilih untuk berbicara menggunakan bahasa Melayu. Selain itu orang Cina Bangka juga tahu bagaimana mengambil hati orang Melayu Bangka yang mayoritas beragama Islam. Orang Cina Bangka paham kalau orang Melayu Bangka suka jika ada orang Cina yang bersedia mengucapkan kata-kata dalam terminologi Islam, jadi selain ungkapan verbal dalam bentuk bahasa Melayu, orang Cina Bangka juga selalu mengucapkan kata-kata atau kalimat yang bernuansa Islami, ungkapan verbal ini menempati urutan ke dua yang paling banyak digunakan oleh orang Cina setelah penggunaan bahasa Melayu misalnya ketika bertemu dengan orang Melayu atau bertamu bahkan ketika memulai sebuah pidato, mereka dengan fasih mengucapkan Assalamualaikum, juga tanpa sungkan menyebut InsyaAllah dan terminologi Islam lainnya seperti Alhamdulilah dan Bismillah. Menariknya mereka juga tahu apa artinya kata-kata tersebut. Ungkapan verbal ke tiga yang juga sering terdengar adalah orang-orang Cina di Bangka dalam percakapannya sering mengucapkan kata-kata bijak misalnya tentang kejujuran, kepercayaan, kalau kita positif maka orang lain akan positif dan prinsip mau mengalah untuk kedamaian. Selanjutnya untuk melengkapi penampilan mereka supaya kelihatan berbaur dan menyatu dengan orang Melayu, orang Cina Bangka 
secara ungkapan verbal tertulisnya menggunakan nama-nama Melayu atau bahkan nama-nama yang bernuansa Islami. Mereka punya nama seperti Taufik Salim, Halim Susanto atau Gunawan. Walaupun begitu mereka tetap memiliki nama dalam bahasa Cina, tetapi tidak digunakan dalam lingkungan eksternal, bahka ada orang tua yang tidak senang jika anaknya dipanggil dengan menggunakan nama Cinanya. Menurut mereka itu nama untuk lingkungan keluarga saja. Menurut peneliti, apa yang digambarkan di atas adalah sebuah bentuk presentasi diri orang Cina Bangka ketika berinteraksi dengan orang Melayu. Informasi yang diketahui orang Cina Bangka mengenai orang Melayu Bangka membantunya untuk mendefinisikan situasi, sehingga memungkinkan orang-orang Cina untuk mengetahui terlebih dahulu apa yang ia harapkan dari dirinya. Berdasarkan pengetahuan tersebut, orang Cina Bangka akan mengetahui bagaimana cara terbaik bertindak untuk menghasilkan respon yang diinginkan darinya.

Etnik Cina Bangka yang mayoritas berasal dari suku Hakka memiliki karakter terbuka dan mudah berbaur dengan penduduk setempat. Hakka memiliki arti "tamu", sehingga memang Cina Hakka yang ada di Bangka sudah terbiasa belajar menyesuaikan diri dengan tempat, orang dan budaya dimana dia menetap. Orang Melayu Bangka memiliki karakter terbuka. Sekilas kedua karakter ini memiliki kecocokan untuk saling berinteraksi. Menurut pengamatan peneliti karakter etnik Melayu Bangka memang terbuka, tetapi sebetulnya mereka tidak ramah terutama kepada orang yang baru dikenal. Etnik Melayu Bangka secara terbuka akan mengeksepresikan perasaannya jika dia tidak menyukai sesuatu atau orang lain atau langsung berkata tidak suka jika dia tidak berkenan atas sikap seseorang. Berdasarkan pengalaman etnik Cina berinteraksi dengan etnik Melayu, etnik Cina ini kemudian memiliki pengetahuan tentang bagaimana menghadapi etnik Melayu supaya kehidupannya menjadi nyaman. Terutama bagaimana menghadapi Melayu dalam urusan bisnis supaya bisnis etnik Cina ini berlangsung lancar dan berkembang dalam jangka panjang. Sedemikian rupa etnik Cina Bangka ini akan mengatur tutur kata (ungkapan verbal) dan perilakunya (ungkapan non verbal) supaya bisa diterima oleh etnik Melayu Bangka dengan positif.

Ciri orang Cina Bangka adalah selalu berusaha menyesuaikan diri dengan gaya orang Melayu termasuk gaya bicara walaupun itu adalah ciri ajaran Islam, tetapi demi kebaikan hubungan dan persamaan dalam pergaulan orang Cina tersebut mau melakukan dramaturgi seperti itu agar presentasi dirinya adalah orang yang mau berbaur dan menerima ajaran orang Melayu walaupun sebetulnya orang Cina itu sendiri masih kukuh mempertahankan adat tradisi Cina secara kepercayaan dan budaya. Walaupun sebetulnya sepanjang pengamatan peneliti berdasarkan pengalaman, orang-orang Cina Bangka agak terkesan kaku dan canggung kalau harus bersikap sopan di depan orang Melayu bisa jadi mereka mau melakukan itu karena dorongan supaya bisa diterima bukan karena memang mereka ingin bersikap seperti sopan dari kehendak dirinya sendiri. Jadi orang-orang Cina ini mau berinteraksi dan mengenal akrab orang Melayu dan mau berbisnis dengan orang Melayu, bahkan mereka rela untuk mengikuti kebiasaan orang Melayu karena bisa mendapatkan keuntungan yaitu keberlangsungan usahanya yang bisa berjalan aman. Termasuk mau 
menggunakan nama Indonesia sebagai nama dirinya atau nama yang diberikan untuk anak-anaknya.

Selain itu afiliasi kelompok memegang peranan penting dalam interaksi antara etnik Cina Bangka dengan etnik Melayu Bangka dalam konteks bisnis. Menurut Muray (dalam Lewin 1978) motif afiliasi merupakan salah satu motif yang sering diartikan sebagai kebutuhan untuk bersama dengan orang lain. Menurut Mc Lleland (1990) bahwa setiap orang pada dasarnya cenderung suka untuk berhubungan dengan orang lain dan beberapa dari mereka mempunyai derajad yang lebih tinggi dalam menyukai interaksi tersebut. Sama halnya seperti yang diungkapkan Neulip (2006) bahwa dalam kompetensi komunikasi antarbudaya juga dibutuhkan willingness to communicate atau kerelaan untuk berkomunikasi. Etnik Cina Bangka dari temuan penelitian menggambarkan etnik ini memiliki kemauan dan motivasi untuk berinteraksi dengan etnik Melayu Bangka. Kebutuhan afiliasi adalah kebutuhan untuk bertemu, bersosialisasi, bertegur sapa, bergabung dan hidup bersama dengan orang lain untuk mendapatkan afeksi dari orang lain. Dalam kebutuhan afiliasi tersebut terkandung kepercayaan, keinginan baik, afeksi, empati yang simpatik yang diwujudkan dalam sikap bersahabat, berusaha menyenangkan orang lain dalam membina hubungan yang penuh kepercayaan. Etnik Cina Bangka terutama dalam konteks bisnis selalu berusaha mengelola presentasi dirinya agar bisa mendapatkan kepercayaan, afeksi dan empatid dari etnik Melayu sehingga akhirnya iklim kondusif untuk perkembangan bisnisnya bisa terjaga.

Apapun akan dilakukan oleh orang Cina Bangka jika hal tersebut dapat membuat bisnisnya berjalan lancar. Orang Cina Bangka berdasarkan pengalamannya memahami bahwa orang Melayu akan baik jika mereka bersikap dan berperilaku positif. Hal ini tidak masalah selama orang Cina Bangka rela melakukannya. Orang Cina Bangka berusaha juga mengendalikan perilaku orang Melayu melalui perilaku positif dirinya. Menurut Goffman (Mulyana: 2004:111), pengendalian ini diperoleh terutama dengan mempengaruhi definisi situasi yang dirumuskan orang lain dan etnik Cina dapat mempengaruhi definisi ini dengan mengekspresikan dirinya sedemikian rupa sehingga mereka dapat memberikan kesan tertentu yang mendorong mereka bertindak secara sukarela seduai dengan rencananya sendiri termasuk menjaga perilaku positif di mata orang Melayu. Orangorang Cina ini berusaha berbuat positif pada orang lain untuk kebaikan di masa datang jika dia membutuhkan sesuatu, kalau dia dikenal positif maka dia yakin akan dibantu. Prinsip mengalah terlihat dari beberapa informan dalam interaksi dengan orang Melayu terutama yang berkaitan dengan interaksi bisnis, prinsip mengalah dan bahwa kalau kita positif maka orang lain akan positif, mereka yakini betul. Bahwa semua perilaku bisnis kita akan berdampak terhadap kelangsungan dan kesuksesan bisnis.

Orang Cina di Bangka sudah memiliki pemahaman dari pengalaman selama bergaul dengan orang Melayu yaitu berusaha untuk menjaga perkataan dan perilaku supaya tidak membuat orang lain sakit hati. Mereka sangat membutuhkankehidupanyangrukundan harmonis Karena itu sangat berpengaruh terhadap kelangsungan bisnis mereka. Kalau ada orang Melayu butuh bantuan termasuk dalam kebutuhan dagang dan barang maka dia akan cepat membantu. 
Tetapi tetap saja kebaikan dalam bentuk bantuan ini dilakukan dengan satu pemikiran bahwa jika suatu saat orang yang kita bantu itu berhasil maka orang tersebut akan bisa membantu kita. Jadi bagi orang Cina apa yang dilakukan hari ini itu harus memberikan efek positif di masa datang. Akibat jangka panjang selalu menjadi perhitungan orang Cina pada setiap aktifitas yang di lakukan. Demi tujuan jangka panjang tersebut etnik Cina Bangka tidak masalah jika harus mengikuti gaya hidup orang Melayu yang suka kumpul-kumpul dan mengobrol selama itu disukai dan diterima oleh orang melayu Bangka. Walaupun sebenarnya orang Cina Bangka lebih suka mengurus usahanya daripada membuang waktu dengan ngobrol, orang Cina Bangka rela melakukannya.

Pengetahuan seseorang tentang budaya orang lain kurang lebih sama dengan persepsi. Agar persepsi seseorang tentang budaya orang lain cenderung tepat, maka minimal harus memahami unsur budaya dominan yaitu nilai-nilai dan kepercayaan budaya orang lain. Ciri-ciri ungkapan verbal dan non verbal juga menjadi bagian dari komponen pengetahuan. Menurut Charles Berger (Neulip, 2006:446) ciri ungkapan verbal dan non verbal dapat membimbing tindakankomunikasidanmempersiapkan seseorang untuk mengantisipasi respon orang lain. Pengetahuan seseorang dapat mengembangkan dan mempertahankan arah pembicaraan secara menyeluruh serta dapat memprediksi tindakan diri sendiri dan orang lain agar tujuan komunikasinya tercapai.

\section{Daftar Pustaka}

Beamer, Linda \& Varner, Iris (2008). Intercultural Communication in The Global Workpalce, Mc GrawHill, New York

Barth, Fredrik (1988). Kelompok Etnik dan Batasannya. Jakarta, UI Press

Goffman, Erving (1959). The Presentation of Self in Everyday Life, The Penguin Press, USA

Gudykunst, William B., \& Asante, Molefe Kete (1989). Handbook of International and Intercultural Communication, Sage Publication, USA

Littlejohn W. Stephen and Foss A. Karen (2005). Theories of Human Communication, Eighth Edition, Thomson, Wadworth, Spain.

Lindlof, Thomas R. (1995). Qualitative Communication Research Methods, Sage Publications.

Mulyana, Deddy (2001). Metodologi Penelitian Kualitatif, Remaja Rosdakarya, Bandung.

Mulyana, Deddy (2012). Cultures and Communication, An Indonesian Scholar's Perspective, Remaja Rosdakarya, Bandung.

Miller, Khaterine (2005) Communication Theories:Perspective, Processes and Context, Mc Graw Hill, New York

Neuliep, W. James (2006). Intercultural Communication, A Contextual Approach, Sage Publication, California.

West, Richard, and Turner,H.Lynn (2007). Introducing Communication Theory, McGraw-Hill Companies, New York.

Wisem, Richard L. (1995). Intercultural Communication Theory, Sage Publication, California, USA

Zhu.Yunxia, Nel. Pieter and Bhat. Ravi (2006). Relationships A Cross Cultural Study of Communication Strategies for Building Business. Downloaded from http://ccm.sagepub.com by adityaindra on April 30, 2008. 